Historic, Archive Document

Do not assume content reflects current scientific knowledge, policies, or practices. 



\section{A Strawberry Tip}

Judge what strawberries will do for you by the same method as you do your fruit trees. Remember they must come from plants that are of high quality. Grown in beds that are new and far enough apart to make sure they are true to name. Plants which have large, strong, vigorous root systems.

Consider the nursery from which they are to come. Is it one which has held up the higher ideals of fruit propagation, of getting you more profit per acre, or one which makes no positive effort? If you are not acquainted with them, get in touch with their patrons.

$t$ is just such inquiries as this that have brought Moncrief a host of satisfed customers. First, they investigate, then prove, finally urge their friends to no longer risk a chance, but purchase their berries from the house with a proven reputation.

You can do no better. Insist on getting Moncrief's Strawberries. In them you will find the superior Moncrief Qualities. A list of his absolute dependable, genuine standard varieties here given, at Special Prepaid-to-Destination Prices.

\section{Moncrief Winfield Nurseries WINFIELD, KANSAS}

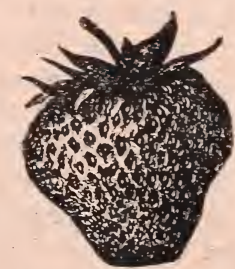



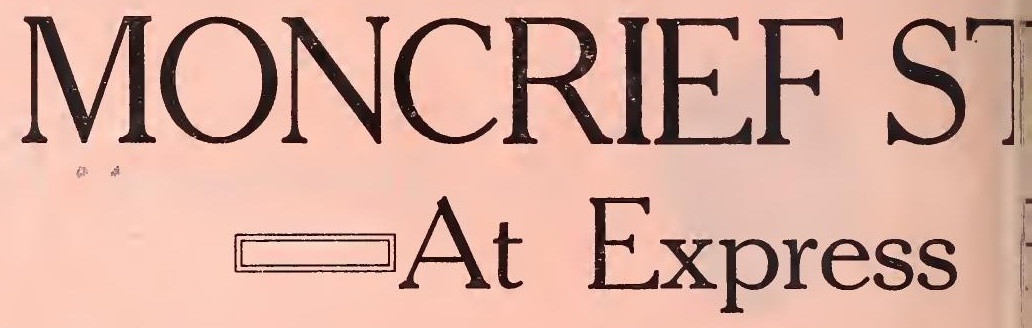

\section{Excelsior (Early)}

This kerry has notonly become famous for the home garden, but for the producer who grows for market purposes. He will get in the Excelsior an extra early berry, one that can be grown profitably, capable of standing drouth and heat. A good berry for any professional grower, especially southern growers. It is a seedling and a WilsonHoffman product. No more of any other extra early variety are grown for the market than the Excelsior and it is recommended for its productiveness.

\section{Klondyke (Medium)}

The popularity of this variety steadily increases. Originating in the South, it was a long time considered as strictly a southern variety, but steadily it has advanced in popularity until today it is grown with large success as far north as the Straits of Mackinac and is becoming an almost universal favorite on the Pacific Coast and throughout the Inter-Mountain states. This variety is noted for its large yields of beautiful berries, uniform in shape; rich blood red in color and having a flavor that is is neither sweet nor sour, but mildly delicious. The berry is full of juice.

\section{Senator Dunlap}

This is the variety for the "millions". It will adapt itself to any soil or kind of culture and is more widely distributed than any variety we know. Especially adapted for the average farmer who has little time for the strawberry bed. If you set them out and hoe them once, you will get some strawberries-many more than you deserve. If you put them on very rich soil, keep most of the runners cut and give them good culture, they will rival the Marshall in size, flavor and general appearance. We sell more plants of the Dunlap every year than any other variety.

\section{Warfield}

This is a grand berry for main crop, both home use and market. Fruit is regular shape, dark red and a splendid shipper. We sell more plants of this than and other variety excepting Senator Dunlap. Resembles Wilson, but is a heavier bearer and better plant maker and better shipper. Plants are small, more like Crescent; requires a strong staminate about every other row for the best results. The dark red color clear through makes it a very desirable home use berry. Warfield will please you in every way. 


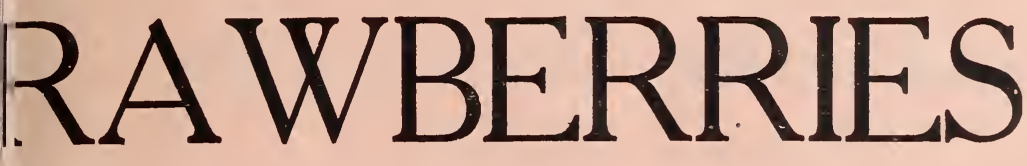

repaid Prices

\section{Aroma}

One of the old standard varieties that, in certain sections, continues to be a favorite, in spite of the many new varieties being introduced. It seems to be better adapted to the south and southwest, although it has been grown very successfully in Michigan. Fruit is very large, bright in color to the center, has a delicious flavor; is very productive and firm of texture, making it a great shipping berry. It has a very long fruiting season and continues good until the end. Plant is is a very strong stocky grower with deep green foliage. The demand for Aroma is usually far in excess of the supply.

\section{Grandy}

More largely grown than eny other variety. It ripens late to very late and the berries are large to very large, bluntly conical, of the firmest texture and bright flame color, which color they retain until they decay; but in flavor it is rather acid and not of the highest quality. It is very nearly perfect in vigor and growth of plant, yet it is a moderately productive variety, except under high culture and upon very most soil. It originated in a meadow in South New Jersey and its peculiarities are its preference for very moist land and the fact that it usually yields more bountifully the second year than the first year.

\section{STRAWBERRY PRICES}

\section{Express Charges Prepaid to Your City}

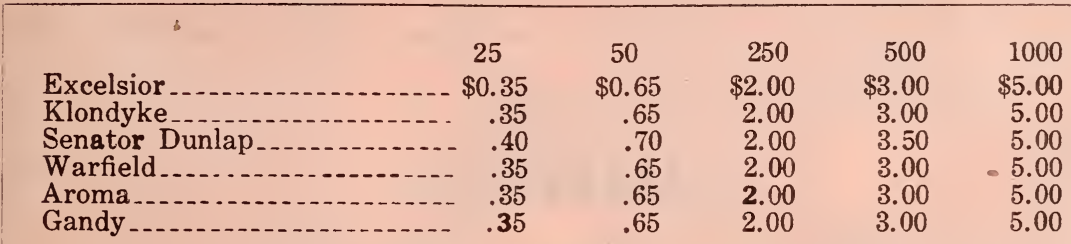

All plants are sold in multiples of 25-that is to say, we cannot sell 30 or 40 , or 70 plants to a customer, because our plants are put up uniformly in bunches of 25 plants each. The number ordered always should be for $25,50,75$, 100 plants, and so on up to whatever number you desire. Plants will be in bunches of 25 whether you order 100 or 100,000 . 


\section{Everbearing Strawberries Express Prepaid}

\section{$\longrightarrow$ \\ Progressive}

A variety originated by Mr. Harlow Rockhill, the introducer of Americus and Francis, in 1908. Two years later he sent it for trial to a number of growers and after a two-year test, it was highly praised by all who tried it. The plant is of medium size, the blossoms strongly staminate and very resistant to heat. Both blossoms and fruit are well protected by the strong healthy foliage. The fruit is rich and sweet, a deep red inside and out, of good medium size with a slight neck and quite firm. Plants set in August and September fruit the next spring and on the runners from July until frost. Spring set plants fruit the same year they are set out.

\section{\&o zovaramanmen of: \\ Superb}

The plants of the Superb are almost ideal growers. The runners are large, long and produce plants in great abundance the first year. The yield of fruit will not be large unless most of the runners are removed as fast as they appear. The second year, the runners do not bother and there will be a large yield of fruit anyway. For best results we advise that the runners of Superb be kept cut and the plants grown in hills. The berries are large, dark red, glossy and the most beautiful of all the fall bearing varieties.

\section{— \\ PRICES}

\section{Express Charges Prepaid}

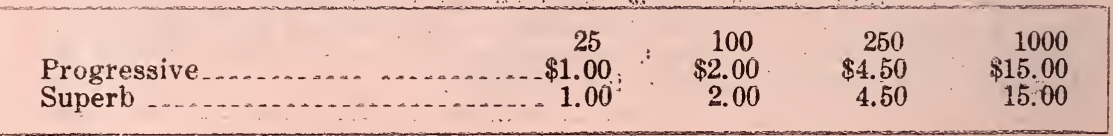

